\title{
Vanadium catalyzed direct synthesis of imines from amines or alcohols and amines by an aerobic oxidative reaction under mild conditions
}

\author{
Lianyue Wang a, Bo Chen ${ }^{\mathrm{a}, \mathrm{b}}$, Lanhui Ren ${ }^{\mathrm{a}, \mathrm{b}}$, Henyun Zhang a, Ying Lü a, Shuang Gao a,* \\ a Dalian National Laboratory for Clean Energy, Dalian Institute of Chemical Physics, Chinese Academy of Sciences, Dalian 116023, Liaoning, China \\ b University of Chinese Academy of Sciences, Beijing 100049, China
}

\section{A R T I C L E I N F}

Article history:

Received 20 June 2014

Accepted 16 July 2014

Published 20 January 2015

Keywords:

Imine

Alcohol

Amine

Aerobic oxidation

Vanadium

\begin{abstract}
A B S T R A C T
The direct synthesis of imines from amines or alcohols and amines by vanadium catalyzed aerobic oxidation was developed. Without an additive or promoter, various symmetrical and unsymmetrical imines were obtained in good to excellent yields under mild conditions with air as an environmentally benign oxidant. The catalyst is very easy to prepare and use, and this catalytic system is also effective for the synthesis of heteroatom-containing imines.
\end{abstract}

(C) 2015, Dalian Institute of Chemical Physics, Chinese Academy of Sciences. Published by Elsevier B.V. All rights reserved.
Imines are an extremely important class of compounds in chemistry and biology that are used in the synthesis of a wide range of biologically and pharmaceutically active compounds, heterocycles, and natural products [1-3]. Imines containing reactive carbon-nitrogen double bonds are versatile intermediates in many organic reactions such as cyclization, reduction, addition, and condensation [4,5]. The traditional procedure for imine synthesis is the condensation reaction of carbonyl compounds with primary amines. This transformation is usually carried out under acidic conditions, and it is limited by the use of the dehydrating agent or apparatus $[6,7]$. The required carbonyl compounds are usually obtained from alcohols by oxidation. Therefore, developing new methods for the direct synthesis of imines is still an essential task in current imine chemistry.

In recent years, a range of methods for the preparation of imines have been developed such as one-pot tandem reactions of alcohols with amines [8-10], self-condensation of primary amines with oxidant [11,12], and oxidation of secondary amines [13,14]. Among these, the dehydrogenative coupling of alcohols with amines under inert oxidant-free conditions has shown high atom efficiency [15-22]. However, in those methods, scarcely available noble metal catalyst complexes or high reaction temperatures are required. A more appealing alternative approach to the synthesis of imines is the direct one-pot oxidative reaction from the greener, cheaper, more readily available and more stable alcohols with amines. Although several reported methods with stoichiometric amounts of reactive oxidant and reagents such as $\mathrm{MnO}_{2}$ or $\mathrm{Ph}(\mathrm{OAc})_{2}$ can achieve this transformation, large amounts of undesired wastes are produced $[23,24]$. From the viewpoint of green and sustainable chemistry, the use of molecular oxygen as the terminal oxidant has advantages, including abundance, low cost, improved safe-

\footnotetext{
*Corresponding author. Tel/Fax: +86-411-84379728; E-mail: sgao@dicp.ac.cn This work was supported by the National Basic Research Program of China (973 Program, 2009CB623505). DOI: 10.1016/S1872-2067(14)60196-0 | http://www.sciencedirect.com/science/journal/18722067 | Chin. J. Catal., Vol. 36, No. 1, January 2015
} 
ty, and benign byproducts. Heterogeneous catalysts such as $\mathrm{Pd}$ [25-27], Pt [28], Au [8,9,29-31], Ag [32], and Ru [33] were employed to achieve this transformation. In this process, the catalyst preparation is complex. Moreover, some of the catalysts require pure oxygen as the oxidant and a high reaction temperature to give high yields of products. Very recently, we developed a non-noble metal heterogeneous $\mathrm{MnO}_{x} / \mathrm{HAP}$ catalyst for the direct imine formation by the oxidative coupling of alcohols and amines in the absence of an additional base using air as the terminal oxidant [34]. Although recently developed transition metals such as $\mathrm{Fe}$ [35], $\mathrm{Cu}$, [36-39], and Pd [40] have been used as catalysts for imine synthesis with molecular oxygen as the terminal oxidant under mild conditions, they need large amounts of ligands, additives, and bases, which make them less attractive for practical purposes. Qiu et al. [41] reported a highly efficient, simple, and versatile transition metal-free aluminum-based metal-organic framework catalytic system for the oxidative coupling of amines to imines.

Vanadium-based catalysts have been widely used in aerobic oxidation reactions [42]. In contrast, vanadium as the catalyst for the aerobic oxidative synthesis of imines is rarely reported. In 2010, Kodama et al. [43] reported the direct synthesis of imines from the oxidation of amines with an oxovanadium complex bearing 3-hydroxypicolinci acid ( $\mathrm{H}_{2}$ phic) under an atmosphere of molecular oxygen, but the catalyst system suffered from the drawbacks of a relatively high temperature, poor substrate scope, and low product yield. Recently, Hanson et al. $[44,45]$ discovered that the vanadium complex $(\mathrm{HQ})_{2} \mathrm{Vv}(\mathrm{O})(\mathrm{O}$ Pr) $(\mathrm{HQ}=8$-quinolinate) could catalyze the oxidation of alcohols to the corresponding carbonyl compounds and $\mathrm{C}-\mathrm{C}$ bond cleavage of lignin models. Here, we demonstrate that the aerobic oxidative synthesis of imines directly from the oxidative reactions of coupling of primary amines and alcohols with amines can be realized with an easily prepared vanadium complex $(\mathrm{HQ})_{2} \mathrm{Vv}(\mathrm{O})\left(\mathrm{O}^{\mathrm{iPr}}\right)$ using air as the oxidant. Without any additional additive or promoter, diverse types of substituted imines were obtained in good to excellent yields under mild conditions.

All chemicals used in this study were analytical grade, commercially available and used without further purification unless otherwise noted. (HQ) ${ }_{2} \mathrm{Vv}(\mathrm{O})(\mathrm{O}$ Pr) was synthesized by the literature method [43]. All experiments were carried out in a Teflon-lined $316 \mathrm{~L}$ stainless steel autoclave (inner volume $100 \mathrm{ml}$ ) equipped with magnetic stirring. GC analysis of yields was performed on an Agilent 7890A with a flame ionization detector (FID). All products were confirmed by GC-MS with an Agilent 7890A GC/5973 MS detector with a SE-54 capillary column, $30 \mathrm{~m} \times 350 \mu \mathrm{m} \times 0.5 \mu \mathrm{m}$. The operating conditions were: FID detector, $300^{\circ} \mathrm{C}$; injection, $250^{\circ} \mathrm{C}$; carrier gas, $\mathrm{N}_{2}(20$ $\mathrm{ml} / \mathrm{min}$ ). All substrates and their products, unless otherwise noted, were detected under the conditions: column temperature, $100{ }^{\circ} \mathrm{C}$ for $7 \mathrm{~min}$, raised to $250{ }^{\circ} \mathrm{C}$ at a rate of $15^{\circ} \mathrm{C} / \mathrm{min}$. To provide sufficient detail to enable others to repeat the experiments, methods already published are indicated by a reference, but new and modified experimental procedures are described in detail, and the compositions of the catalysts are given clearly.
For a general procedure for the oxidation of amines to imines, a mixture of catalyst $\mathrm{V}\left(21 \mathrm{mg}, 0.05 \mathrm{mmol}\right.$ ) in $\mathrm{CH}_{3} \mathrm{CN}$ (2 $\mathrm{ml}$ ) was stirred for $1 \mathrm{~min}$ at room temperature in a 25 -ml flask. Then, benzylamine (107 $\mathrm{mg}, 1 \mathrm{mmol}$ ) was added to the mixture. The resulting mixture was transferred to an autoclave. After the autoclave was sealed, air was charged to $0.1 \mathrm{MPa}$. The mixture was stirred at $60{ }^{\circ} \mathrm{C}$. After the reaction was completed, the reactor was quickly cooled to room temperature. Excess air was depressurized slowly. GC analysis of the reaction mixtures using biphenyl as an internal standard gave 96\% yield of $N$-(benzylidene)benzylamine.

For a general procedure for the oxidation of alcohols and amines to imines, a mixture of catalyst $\mathrm{V}(21 \mathrm{mg}, 0.05 \mathrm{mmol})$ in $\mathrm{ClCH}_{2} \mathrm{CH}_{2} \mathrm{Cl}(2 \mathrm{ml})$ was stirred for $1 \mathrm{~min}$ at room temperature in a $25-\mathrm{ml}$ flask. Then, benzyl alcohol (216 $\mathrm{mg}, 2 \mathrm{mmol}$ ) and aniline (93 $\mathrm{mg}, 1 \mathrm{mmol}$ ) were added to the mixture. The resulting mixture was transferred to an autoclave. After the autoclave was sealed, air was charged to $0.1 \mathrm{MPa}$. The mixture was stirred at $80^{\circ} \mathrm{C}$. After the reaction was completed, the reactor was quickly cooled to room temperature. Excess air was depressurized slowly. GC analysis of the reaction mixtures using biphenyl as an internal standard gave $85 \%$ yield of $\mathbf{5 a}$.

For a general procedure for obtained isolated yield, after reaction, the solvent was concentrated in vacuo, and the resultant crude mixture was purified by column chromatography on neutral alumina gel with a mixture of ethyl acetate/petroleum ether/triethylamine as eluent. The alumina gel was preneutralized with $1 \%(v / v)$ triethylamine in petroleum ether before packing.

Initially, a range of catalysts were applied to the transformation of benzylamine to $\mathrm{N}$-(benzylidene)benzylamine in toluene under an atmosphere of air at $60^{\circ} \mathrm{C}$ (Table 1, entries 1-4). Among the catalysts examined, $(\mathrm{HQ})_{2} \mathrm{Vv}(\mathrm{O})\left(\mathrm{O}^{i} \mathrm{Pr}\right)$ was found to be the best catalyst for this transformation with $83 \%$ yield. Other vanadium catalysts such as $\mathrm{VOSO}_{4}$ and $\mathrm{V}_{2} \mathrm{O}_{5}$ showed lower catalytic activity. The catalyst precursor $\mathrm{VO}$ (acac)2 gave a low yield of the product. The nature of the solvent had a crucial impact on the reaction. Thus, several solvents were screened. $\mathrm{CH}_{3} \mathrm{CN}$ as solvent gave the best catalytic activity compared to other solvents such as toluene, $\mathrm{ClCH}_{2} \mathrm{CH}_{2} \mathrm{Cl}$, and $\mathrm{MeOH}$ (Table 1, entries 6-8). When the temperature was decreased to $40{ }^{\circ} \mathrm{C}$, only $40 \%$ yield was obtained, suggesting that an elevated temperature was essential for a high yield of the product (Table 1,

\section{Table 1}

Optimization of reaction conditions.

\begin{tabular}{|c|c|c|c|}
\hline Entry & Catalyst & Solvent & Yield a (\%) \\
\hline 1 & $\mathrm{VOSO}_{4}$ & toluene & 1.3 \\
\hline 2 & $\mathrm{~V}_{2} \mathrm{O}_{5}$ & toluene & 0.53 \\
\hline 3 & $\mathrm{VO}(\text { acac })_{2}$ & toluene & 2.6 \\
\hline 4 & $(\mathrm{HQ})_{2} \mathrm{~V}^{2}(\mathrm{O})\left(\mathrm{O}^{\mathrm{i}} \mathrm{Pr}\right)$ & toluene & 83 \\
\hline $5^{b}$ & $(\mathrm{HQ})_{2} \mathrm{~V}^{\mathrm{v}}(\mathrm{O})\left(\mathrm{O}^{\mathrm{i}} \mathrm{Pr}\right)$ & toluene & 86 \\
\hline 6 & $(\mathrm{HQ})_{2} \mathrm{~V}^{\mathrm{v}}(\mathrm{O})\left(\mathrm{O}^{\mathrm{i}} \mathrm{Pr}\right)$ & $\mathrm{CH}_{3} \mathrm{CN}$ & 96 \\
\hline 7 & $(\mathrm{HQ})_{2} \mathrm{Vv}(\mathrm{O})(\mathrm{O} \mathrm{Pr})$ & $\mathrm{ClCH}_{2} \mathrm{CH}_{2} \mathrm{Cl}$ & 70 \\
\hline 8 & $(\mathrm{HQ})_{2} \mathrm{~V}^{\mathrm{v}}(\mathrm{O})\left(\mathrm{O}^{\mathrm{i}} \mathrm{Pr}\right)$ & $\mathrm{MeOH}$ & 27 \\
\hline $9^{c}$ & $\left(\mathrm{HQ}_{2}\right)_{2}(\mathrm{O})\left(\mathrm{O}^{\mathrm{i}} \mathrm{Pr}\right)$ & $\mathrm{CH}_{3} \mathrm{CN}$ & 40 \\
\hline
\end{tabular}


entry 9).

With the optimized reaction conditions, we proceeded to explore the substrate scope of this transformation. The results are summarized in Table 2 . Our catalytic system showed that a wide range of functional groups were tolerated under the reaction conditions. Substrates substituted with both electron-donating and electron-withdrawing groups at different positions worked well and afforded the desired products in excellent yields (Table 2, entries 1-12). Notably, the present catalytic system also worked with heteroaromatic compounds

Table 2

Vanadium catalyzed aerobic oxidation of primary amines to imines under air.

(n)

Reaction conditions: amine $1 \mathrm{mmol}$, catalyst $\mathrm{V} 5 \mathrm{~mol} \%, \mathrm{CH}_{3} \mathrm{CN} 2 \mathrm{ml}, 0.1$ MPa air, $60^{\circ} \mathrm{C}, 12-24 \mathrm{~h}$.

a Determined by GC and confirmed by GC-MS, values in parenthesis are the yields of the isolated products. such as (pyridin-3-yl)methanamine and gave the products in excellent yields (Table 2, entry 13). In the case of $\mathbf{1 n}, 93 \%$ of $\mathbf{2 n}$ was obtained (Table 2, entry 14). However, the reaction of aliphatic amine was not efficient, and only a trace amount of product was detected (Table 2, entry 15).

The successful transformation of benzylamines into the corresponding imines under mild conditions prompted us to investigate the generality of this method for the synthesis of unsymmetrical imines with various alcohol and amine substrates. To our delight, we found that this transformation is very general for a wide range of alcohols and amines and could produce the corresponding imines in good yields (Table 3). Initially, the reaction conditions were screened using the reaction of benzyl alcohol with aniline. Yields were determined by GC analysis using an internal standard. The products were confirmed by $\mathrm{GC}-\mathrm{MS}$. $\mathrm{ClCH}_{2} \mathrm{CH}_{2} \mathrm{Cl}$ was demonstrated to be the most suitable solvent for this transformation. A satisfactory result was obtained in $\mathrm{ClCH}_{2} \mathrm{CH}_{2} \mathrm{Cl}$ at $80{ }^{\circ} \mathrm{C}$. Thus, the synthesis of unsymmetrical imines was carried out by the reactions of various aromatic alcohols with aniline (Table 3, entries 1-9). Benzylic alcohols with electron-donating and electron-withdrawing groups gave good to excellent yields of products (Table 3, entries 1-6). Excellent yield was unexpectedly obtained for 4-nitrobenzyl alcohol, which contains a strongly electron-withdrawing group (Table 3, entry 6). Surprisingly, the present catalytic system was also very effective for the oxidation reactions of heteroatom alcohols with aniline, giving the desired products in good yields (Table 3, entries 7 and 8). However, the catalytic system displayed low activity in the oxidation of allylic alcohols for imine synthesis. For example, cinnamyl alcohol was selectively oxidized to the corresponding imine with only $35 \%$ yield (Table 3 , entry 9 ).

Next, the reactions between benzyl alcohol and different amines were examined under the same reaction conditions (Table 3). Similarly, substituted anilines gave the corresponding imines in good yields (Table 3, entries 10-12). In the case of a cyclic secondary amine and a primary aliphatic amine, the desired products were obtained in $64 \%$ and $56 \%$ yields, respectively (Table 3, entries 13 and 14).

In summary, we developed an effective approach for the synthesis of symmetrical and unsymmetrical imines using $\mathrm{V}$ catalyzed aerobic oxidative reactions of amines and alcohols with amines under mild conditions. Without any additive or promoter, various imines were obtained in good to excellent yields under mild conditions with air as an environmentally benign oxidant. Importantly, this catalytic system was also effective for the synthesis of imines containing a heteroatom.

\section{References}

[1] Murahashi S I. Angew Chem Int Ed, 1995, 34: 2443

[2] Gawronski J, Wascinska N, Gajewy J. Chem Rev, 2008, 108: 5227

[3] Adams J P.J Chem Soc, Perkin Trans 1, 2000: 125

[4] Layer R W. Chem Rev, 1963, 63: 489

[5] Gawronski J, Wascinska N, Gajewy J. Chem Rev, 2008, 108: 5227

[6] Taguchi K, Westheimer F H.J Org Chem, 1971, 36: 1570

[7] Das B, Ravikanth B, Laxminarayana K, Rao B V.J Mol Catal A, 2006, 
Table 3

Vanadium catalyzed aerobic oxidation of alcohols and amines to imines under air.

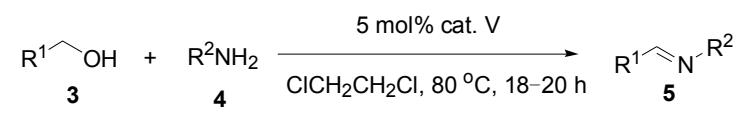

\begin{tabular}{|c|c|c|c|c|}
\hline Entry & Substrate $\mathbf{3}$ & Substrate 4 & Product & Yield a (\%) \\
\hline 1 & & & & 85 \\
\hline 2 & & & & 76 \\
\hline 3 & & & & 86 \\
\hline 4 & & & & 70 \\
\hline 5 & & & & 83 \\
\hline 6 & & & & 98 \\
\hline 7 & & & & 89 \\
\hline 8 & & & & 43 \\
\hline 9 & & & & 35 \\
\hline 10 & & & & 82 \\
\hline 11 & & & & 79 \\
\hline 12 & & $-I V I$ & & 70 \\
\hline 13 & & & & 64 \\
\hline 14 & & & & 56 \\
\hline
\end{tabular}

Reaction conditions: alcohol $2 \mathrm{mmol}$, amine $1 \mathrm{mmol}$, catalyst $5 \mathrm{~mol} \%, \mathrm{ClCH}_{2} \mathrm{CH}_{2} \mathrm{Cl} 2 \mathrm{ml}, 0.1 \mathrm{MPa}$ air, $80{ }^{\circ} \mathrm{C}, 18-20 \mathrm{~h}$. a Determined by GC and confirmed by GC-MS, yield based on amine to imine.

253: 92

[8] Sun H, Su F Z, Ni J, Cao Y, He H Y, Fan K N. Angew Chem Int Ed, 2009, 48: 4390

[9] Kegnæs S, Mielby J, Mentzel U V, Christensen C H, Riisager A. Green Chem, 2010, 12: 1437

[10] Gnanaprakasam B, Zhang J, Milstein D. Angew Chem Int Ed, 2010, 49: 1468

[11] Su F Z, Mathew S C, Mohlmann L, Antonietti M, Wang X C, Blechert S. Angew Chem Int Ed, 2011, 50: 657

[12] Grirrane A, Corma A, Garcia H.J Catal, 2009, 264: 138

[13] Zhu B L, Angelici R J. Chem Commun, 2007: 2157

[14] So M H, Liu Y G, Ho C M, Che C M. Chem Asian J, 2009, 4: 1551
[15] Gunanathan C, Ben-David Y, Milstein D. Science, 2007, 317: 790

[16] Watson A J A, Williams J M J. Science, 2010, 329: 635

[17] Watson A J A, Maxwell A C, Williams J M J. Org Lett, 2009, 11: 2667

[18] Bala M, Verma P K, Kumar N, Sharma U, Singh B. Can J Chem, 2013, 91: 732

[19] Perez J M, Cano R, Yus M, Ramon D J. Eur J Org Chem, 2012, 2012: 4548

[20] Cano R, Ramon D J, Yus M.J Org Chem, 2011, 76: 5547

[21] Tang L, Sun H Y, Li Y F, Zha Z G, Wang Z Y. Green Chem, 2012, 14: 3423

[22] Reddy M M, Kumar M A, Swamy P, Naresh M, Srujana K, Satyanarayana L, Venugopal A, Narender N. Green Chem, 2013, 15: 3474 


\section{Graphical Abstract}

Chin. J. Catal., 2015, 36: 19-23 doi: 10.1016/S1872-2067(14)60196-0

Vanadium catalyzed direct synthesis of imines from amines or alcohols and amines by an aerobic oxidative reaction under mild conditions

Lianyue Wang, Bo Chen, Lanhui Ren, Henyun Zhang, Ying Lü, Shuang Gao*

Dalian Institute of Chemical Physics, Chinese Academy of Sciences; University of Chinese Academy of Sciences

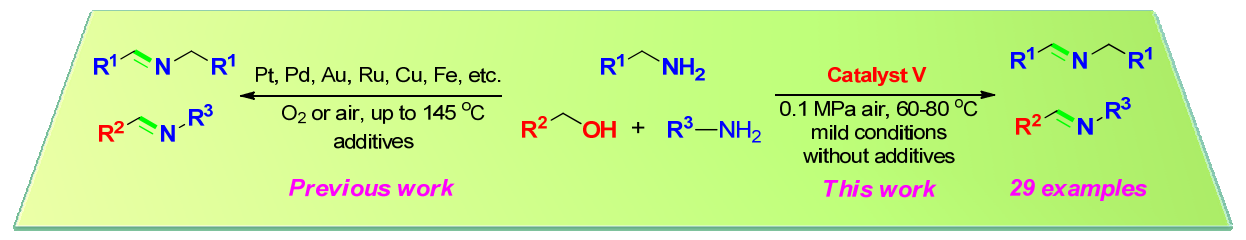

An effective approach to the synthesis of symmetrical and unsymmetrical imines by vanadium catalyzed aerobic oxidative reactions of amines and alcohols with amines under mild conditions was developed.

[23] Blackburn L, Taylor R J K. Org Lett, 2001, 3: 1637

[24] Yusubov M S, Chi K W, Park J Y, Karimov R, Zhdankin V V. Tetrahedron Lett, 2006, 47: 6305

[25] Kwon M S, Kim S, Park S, Bosco W, Chidrala R K, Park J. J Org Chem, 2009, 74: 2877

[26] Cui W J, Bao Z, Jia M L, Ao W L, Zhu H Y. RSC Adv, 2014, 4: 2601

[27] Furukawa S, Suga A, Komatsu T. Chem Commun, 2014, 50: 3277

[28] He W, Wang L D, Sun C L, Wu K K, He S B, Chen J P, Wu P, Yu Z K. Chem Eur J, 2011, 17: 13308

[29] Soule J F, Miyamura H, Kobayashi S. Chem Commun, 2013, 49: 355

[30] Zhang L L, Wang W T, Wang A Q, Cui Y T, Yang X F, Huang Y Q, Liu X Y, Liu W G, Son J Y, Oji H, Zhang T. Green Chem, 2013, 15: 2680

[31] Neeli C K P, Ganji S, Ganjala V S P, Kamaraju S R R, Burri D R. RSC $A d v, 2014,4: 14128$

[32] Mielby J, Poreddy R, Engelbrekt C, Kengnæs S. Chin J Catal (催化学 报), 2014, 35: 670

[33] Kim J W, He J L, Yamaguchi K, Mizuno N. Chem Lett, 2009, 38: 920
[34] Chem B, Li J, Dai W, Wang L Y, Gao S. Green Chem, 2014, 16: 3328

[35] Zhang E L, Tian H W, Xu S D, Yu X C, Xu Q. Org Lett, 2013, 15: 2704

[36] Kang Q Zhang Y G. Green Chem, 2012, 14: 1016

[37] Huang B, Tian H W, Lin S S, Xie M H, Yu X C, Xu Q. Tetrahedron Lett, 2013, 54: 2861

[38] Tian H W, Yu X C, Li Q, Wang J X, Xu Q. Adv Synth Catal, 2012, 354: 2671

[39] Wang J Q, Lu S L, Cao X Q, Gu H W. Chem Commun, 2014, 50: 5637

[40] Jiang L, Jin L L, Tian H W, Yuan X Q, Yu X C, Xu Q. Chem Commun, 2011, 47: 10833

[41] Qiu X, Len C, Luque R, Li Y W. ChemSusChem, 2014, 7: 1684

[42] Punniyamurthy T, Velusamy S, Iqbal J. Chem Rev, 2005, 105: 2329

[43] Kodama S, Yoshida J, Nomoto A, Ueta Y, Yano S, Ueshima M, Ogawa A. Tetrahedron Lett, 2010, 51: 2450

[44] Hanson S K, Wu R L, Silks L A P. Org Lett, 2011, 13: 1908

[45] Hanson S K, Wu R L, Silks L A P. Angew Chem Int Ed, 2012, 51: 3410

\section{温和条件下钒催化氧化胺、醇和胺直接合成亚胺 \\ 王连月 ${ }^{\mathrm{a}}$ ，陈 波 ${ }^{\mathrm{a}, \mathrm{b}}$ ，任兰会 ${ }^{\mathrm{a}, \mathrm{b}}$ ，张恒耘 ${ }^{\mathrm{a}}$, 吕 迎 ${ }^{\mathrm{a}}$, 高 爽 ${ }^{\mathrm{a}}{ }^{*}$ \\ ${ }^{\mathrm{a}}$ 中国科学院大连化学物理研究所洁净能源国家实验室(筹), 辽宁大连 116023 \\ ${ }^{\mathrm{b}}$ 中国科学院大学, 北京 100049}

摘要: 开发了钒催化氧化胺、醇和胺直接合成亚胺催化体系, 无须额外的添加剂或促进剂, 空气作为环境友好的氧源, 温和条件下, 能高收率地得到各种对称和非对称亚胺, 并且催化剂非常容易制备和使用. 该催化体系对含杂原子亚胺的合成也非常有效.

关键词: 亚胺; 醇; 胺; 需氧氧化; 钒

收稿日期: 2014-06-20. 接受日期: 2014-07-16. 出版日期: 2015-01-20.

*通讯联系人. 电话/传真: (0411)84379728; 电子信箱: sgao@dicp.ac.cn

基金来源：国家重点基础研究发展计划(973计划, 2009CB623505).

本文的英文电子版由Elsevier出版社在ScienceDirect上出版(http://www.sciencedirect.com/science/journal/18722067). 